\title{
PENURUNAN GEJALA BABY BLUES MELALUI TERAPI MUSIK KLASIK MOZART PADA IBU POST PARTUM
}

\author{
Fitri Nuriya Santy ${ }^{1}$, Siti Noviana Wahid ${ }^{2}$ \\ ${ }^{1,2}$ Akademi Keperawatan Panca Bhakti Bandar Lampung \\ E-mail : fitri@pancabhakti.ac.id
}

\begin{abstract}
Abstrak
Kelahiran seorang bayi menegaskan suatu status baru bagi seorang perempuan, yaitu menjadi seorang ibu. Adanya status baru ini menuntut ibu untuk melakukan berbagai penyesuaian yang dapat mengakibatkan stress baik secara fisik maupun psikologis. Baby blues merupakan masalah psikologis yang sering muncul pada ibu postpartum. Gejala dari baby blues ini mengakibatkan perasaan yang tidak nyaman bagi ibu dan dapat berlanjut menjadi gangguan psikologis yang lebih berat. Oleh karna itu perlu penanganan yang baik untuk menurunkan gejala baby blues pada ibu postpartum. Tujuan dari penelitian ini adalah mengetahui dan menganalisa efektifitas terapi musik klasik mozartuntuk mengurangi gejala baby blues pada ibu Post partum. Metode yang digunakan dalam penelitian ini menggunakan metode kualitatif pendekatan studi kasus, yaitu memberikan gambaran terhadap suatu masalah. Instrument untuk menilai gejala baby blues pada penelitian ini menggunakan Edinburgh Postnatal Depression Scale (EPDS). Hasil penelitian ini menunjukan bahwa setelah diberikan penerapan terapi musik klasik mozart pada kedua responden terjadi penurunan terhadap gejala baby blues. Kesimpulan dari penelitian ini bahwa penerapan terapi musik klasik mozart pada kedua responden efektif untuk menurunkan gejala baby blues. Penelitian ini diharapkan menambah pengetahuan profesi keperawatan dalam menerapkan intervensi terapi musik klasik mozart untuk menurunkan gejala baby blues pada ibu postpartum.
\end{abstract}

Kata kunci: Baby blues, Musik klasik mozart, Postpartum

\begin{abstract}
The birth of a baby confirms a new status for a woman, which is to be a mother. The existence of this new status requires mothers to make various adjustments that can cause stress both physically and psychologically. Baby blues are psychological problems that often occur in postpartum mothers. The symptoms of these baby blues result in feelings of discomfort for the mother and can progress to more severe psychological disorders. It needs good treatment to reduce the symptoms of baby blues in postpartum mothers. The aim of this research is to find out and analyze the effectiveness of mozart classical music therapy to reduce the symptoms of baby blues in Post partum mothers. The method used in this study is to provide a description of a problem. The instrument for assessing baby blues symptoms in this study used the Edinburgh Postnatal Depression Scale (EPDS). The results of this study indicate that after being given the application of mozart classical music therapy in both respondents there was a decrease in the symptoms of baby blues. The conclusion of this study is that the application of mozart classical music therapy in both respondents was effective in reducing the symptoms of baby blues. This research is expected to increase the knowledge of the nursing profession in implementing classical mozart music therapy interventions to reduce the symptoms of baby blues in postpartum mothers.
\end{abstract}

Keywords: Baby blues, Mozart classical music, Postpartum 


\section{PENDAHULUAN}

Kelahiran seorang bayi merupakan salah satu peristiwa yang paling membahagiakan dalam kehidupan perempuan. Kehadiran bayi menegaskan suatu status baru bagi seorang perempuan, yaitu menjadi seorang ibu. Adanya status baru ini di sisi lain ternyata menuntut ibu untuk melakukan berbagai penyesuaian. Salah satu bentuk penyesuaian yang harus dilakukan oleh seorang ibu yang baru melahirkan adalah mengikuti ritme kehidupan bayi. Keharusan untuk melakukan penyesuaian ini menyebabkan ibu sangat tertekan yang mana ini akan mengakibatkan stress baik secara fisik maupun psikologis (Dewi, F \& Sunarsih, T, 2012).

Masalah psiokologis yang sering muncul pada ibu Post partum Secara umum ada tiga gangguan psikologis utama pasca persalinan, dari yang ringan sampai berat yaitu Post partum Blues atau lebih sering dikenal Baby blues, depresi Post partum dan Post partum Psikosis (Marmi, S. 2012). Baby blues merupakan suatu gangguan perasaan yang dialami ibu Post partum, baby blues ini merupakan depresi yang paling ringan dan hampir setiap ibu Post partum mengalami baby blues, oleh sebab itu sering tidak diperdulikan sehingga tidak terdiagnosis dan tidak di tatalaksanai sebagaimana seharusnya, akhirnya dapat menjadi masalah yang menyulitkan, tidak menyenangkan dan dapat membuat perasaan perasaan tidak nyaman bagi wanita yang mengalaminya, dan bahkan kadang-kadang gangguan ini dapat berkembang menjadi keadaan yang lebih berat yaitu depresi dan psikosis pasca salin, yang mempunyai dampak lebih buruk.

Dari beberapa hasil penilitian ditemukan kasus ibu yang mendapat Baby blues danPostnatal Depression cukup tinggi, yaitu:Satu dari dua ibu yang melahirkan (50\%) pernah mengalami Baby blues, dan sekitar 10\% akan berlanjut menjadi Postnatal Depression. Sekitar 70\% dari semua ibu yang melahirkan pernah mengalami Baby blues, dan sekitar 10\%-20\% dari ibu-ibu yang baru melahirkan mengalami

Postpartum Depression.Sekitar 10\%-22\% ibu-ibu yang baru pertama melahirkan menderita Postpartum Psychosis, satu dari dua ibu yang melahirkan dalam beberapa menit atau beberapa jam pertama setelah melahirkan, merasa bahagia, kemudia secara tiba-tiba tanpa sebab yang jelas. (Susanti dan Sulistiyanti, 2017). Angka kejadian baby blues didunia berkisar antara 0,5\% - 60\%, angka kejadian Baby blues di Asia berkisar 3,5\% - 63,3\% dan angka persentase kejadian baby blues di Indonesia berkisar 50-70\% Angka persentase tersebut menunjukan bahwa 50-70 wanita akan mengalami baby blues pasca melahirkan (Susanti dan Sulistiyanti, 2017).

Menurut Asih dan Risneni (2016) secara garis besar penanganan pada baby blues dibutuhkan 
penanganan ditingkat prilaku, emosional, intelektual, sosial dan psikologis secara bersama-sama, dengan melibatkan lingkungannya yaitu: suami, keluarga dan juga teman dekatnya, dengan cara pendekatan komunikasi teraupetik dan juga peningkatan support mental pada ibu postpartum yang mengalami baby blues. Selain menggunakan pendekatan komunikasi teraupetik dan juga peningkatan support mental, Terapi Musik Klasik Mozart dapat dimanfaatkan untuk membantu mengurangi gejala baby blues.

Musik secara luas digunakan untuk meningkatkankesejahteraan, mengurangi stres, dan mengalihkan perhatian pasien dari gejala yang tidak menyenangkan, sehingga dengan demikian jelas bahwa terapi musik berpengaruh terhadap kondisi emosional seseorang. Musik tersebut akan merangsang pengeluaran gelombang otak yang dikenal sebagai gelombang a yang memiliki frekuensi 8-12 cps (cycles per second). Pada saat gelombang a dikeluarkan otak memproduksi serotonin yang membantu menjaga perasaan bahagia dan membantu dalam menjaga mood, dengan cara membantu tidur, perasaan tenang serta melepaskan depresi dan endorphin yang menyebabkan seseorang merasa nyaman tenang dan euphoria (Asih dan Risneni, 2016)

Musik yang menempatkan kelasnya sebagai musik bermakna medis adalah musik klasik, karena musik ini magnitude yang luar biasa dalam perkembangan ilmu kesehatan, diantaranya memiliki nada yang lembut dan teratur, memberikan stimulasi gelombang alfa, ketenangan, dan membantu pendengarnya lebih rileks. Sehingga dapat di intervensikan untuk ibu Post Partum yang mengalami baby blues. Jenis musik klasik, yang dianjurkan banyak dari peneliti adalah jenis musik klasik Mozart karena aplikasi medis musik Mozart lebih membuktikan hasil yang menakjubkan bagi perkembangan ilmu kesehatan. Musik-musik klasik Mozart memiliki keunggulan akan kemurnian dan kesederhanaan, bunyi yang dimunculkan merupakan Irama, melodi, dan frekuensifrekuensi tinggi, musik klasik Mozart merangsang dan memberi daya pada daerahdaerah kreatif. Hal ini dibuktikan pada penelitian Permatasari et al. (2015) dalam penelitiannya pada ibu Post Partum yang mengalami baby blues di salah satu desa Provinsi Riau, didapatkan hasil bahwa gejala baby blues pada ibu postpartum dapat berkurang lebih cepat jika dibantu menggunakan terapi musik klasik Mozart, dari pada ibu postpartum yang mengalami baby blues tetapi tidak menggunakan terapi musik klasik Mozart.

\section{METODOLOGI}

Desain yang digunakan dalam penelitian ini menggunakan metode kualitatif pendekatan studi kasus yang tujuannya untuk memberi gambaran atau deskripsi terhadap fenomenan yang diteliti dari partisipan. Jenis pendekatan studi kasus dalam penelitian ini yaitu 
menggunakan studi kasus multiple. Tujuan studi kasus ini adalah studi untuk mengeksplorasi masalah asuhan keperawatan pada ibu Postpartum yang mengalami Baby blues menggunakan Terapi Musik Klasik Mozart di wilayah kerja Puskesmas Gedong Air Bandar Lampung.

Subjek dalam intervensi ini yaitu ibu post partum yang mengalami baby blues dengan jumlah minimal dua subjek. Adapun kriteria inklusi Dalam penelitian ini yaitu ibu post partum kurang dari 2 minggu pasca melahirkan dan berusia kurang dari 35 tahun serta memiliki beberapa gejala baby blues, mampu melakukan aktivitas ringan serta bersedia menjadi subjek penelitian

Metode pengambilan data dilakukan dengan melakukan skrining menggunakan Edinburgh postnatal depression scale untuk mengetahui adanya gejala baby blues pada ibu post partum. Edinburg Postnatal Depression Scale (EPDS) yaitu kuesioner dengan validitas yang telah teruji yang dapat mengukur intensitas perubahan suasana hati pascabersalin. Pertanyaan-pertanyaannya berhubungan dengan labilitas perasaan kecemasan, perasaan bersalah, serta mencakup hal-hal yang mencakup post-partum blues. Kuesioner ini terdapat 10 pertanyaan dimana setiap pertanyaan memiliki 4 pilihan jawaban yang mempunyai nilai atau skor yang harus di pilih salah satu yang sesuai dengan gradasi perasaan yang dirasakan ibu setelah bersalin saat itu. Pertanyaan tersebut harus dijawab sendiri oleh ibu dan rata-rata harus diselesaikan dalam waktu 5 menit. Kuesioner tersebut telah teruji validitasnya di beberapa negara seperti Belanda, Swedia, Australia, Indonesia, dan Italia (Dewi dan Sunarsih, 2012).

Alat ukur Edinburgh postnatal depression scala memiliki nilai maksimal 30, yakni setiap pertanyaan memiliki rentang nilai 0-3. Pertanyaan 1,2 dan 4 mendapat nilai $0,1,2$ atau 3 dengan jawaban paling atas mendapat nilai 0 dan jawaban paling bawah mendapat nilai 3. Sedangkan pertanyaan 3,5 sampai 10 merupakan penilaian terbalik dengan jawaban paling atas mendapat nilai 3 dan jawaban paling bawah mendapat nilai 0.Apabila nilai EPDS 8-12 maka ibu mengalami baby blues, dan jika nilai > 12 maka ibu mengalami depresi postpartum yang dapat terjadi >14 hari setelah melahirkan. Pertanyaan ke 10 dalam EPDS merupakan pertanyaan yang nenunjukan keinginan bunuh diri, ini perlu diperhatikan karna keinginan bunuh diri adalah gejala dari Postpartum Psikosis.

Penelitian ini dilakukan di wilayah kerja puskesmas Gedong Air Bandar Lampung, pada tanggal 22 sampai 27 Mei 2019, dalam hal ini analisa data yang dilakukan dengan menggunakan nilai edinburgh postnatal depression scale sebelum dan sesudah dilakukan terapi musik klasik Mozart terhadap 2 subjek penelitian. Untuk 
melindungi partisipan dari berbagai kekhawatiran, peneliti menggunakan beberapa prinsip etik yang sesuai dengan konteks penelitian ini, prinsip etik yang diterapkan dalam penelitian ini meliputi beneficence, respect for human dignity dan Justice.

\section{HASIL}

Menurut hasil grafik dari penilaian Edinburgh Postnatal Depression Scala sebelum dan sesudah dilakukan terapi musik klasik Mozart pada Ny. L dan Ny. E selama 3 hari berturut turut yaitu:

Grafik 1. Penilaian EPDS sebelum dan sesudah dilakukan terapi music klasik Mozart pada Ny. L

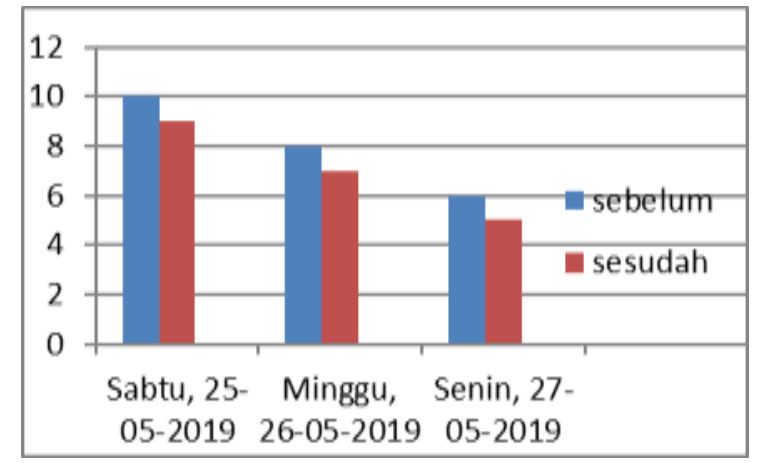

Grafik 1. Penilaian EPDS sebelum dan sesudah dilakukan terapi music klasik Mozart pada Ny.E

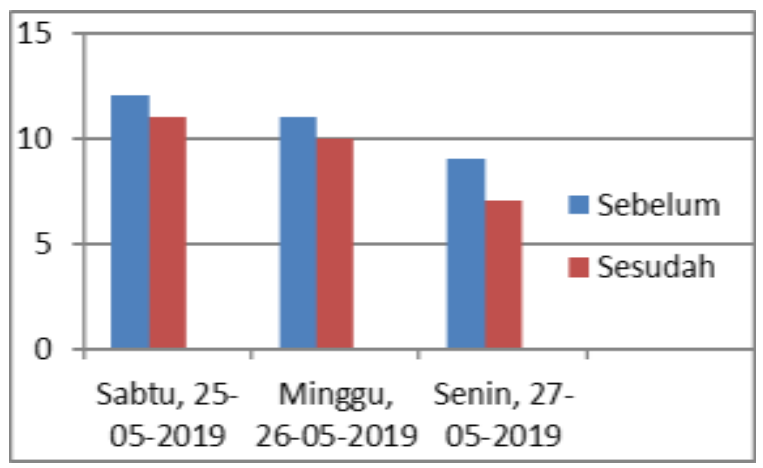

Melalui observasi peneliti, bahwa sebelum dilakukan terapi musik klasik Mozart pada Ny. L nilai EPDS 10.Setelah diberikan terapi musik klasik mozart pada Ny. L nilai EPDS menurun menjadi 9, pada hari ke-2 setelah diberikan terapi musik klasik Mozart pada Ny. L nilai EPDS menurun menjadi 7, pada hari ketiga setelah diberikan terapi musik klasik Mozart nilai EPDS Ny. L menurun menjadi 5, nilai 5 yang berarti Ny. L sudah tidak dikategorikan baby blues (Nilai baby blues 8-12).

Pada Ny. E nilai EPDS sebelum diberikan terapi musik klasik Mozart adalah 12, Setelah diberikan terapi musik klasik Mozart pada Ny. E nilai EPDS berubah menjadi 11, pada hari ke-2 setelah diberikan terapi musik klasik Mozart nilai EPDS menurun menjadi 10, pada hari ketiga setelah diberikan terapi musik klasik Mozart nilai EPDS menurun menjadi 7, nilai 7 yang berarti Ny. E sudah tidak dikategorikan baby blues( Nilaibaby blues 812).

\section{PEMBAHASAN}

Berdasarkan hasil penelitian pada saat pengkajian klien 1 dan 2, nilai edinburgh postnatal depression scale membuktikan klien 1 dan 2 mengalami baby blues, klien 1 dengan nilai 10 dan klien 2 dengan nilai 12, yang mana sesuai dengan pendapat Asih dan Risneni (2016) bahwadapat dikategorikan baby bluesjika nilai EPDS 8-12.

Baby blues adalah suatu gangguan perasaan yang dialami ibu post partum, baby bluesmerupakan depresi yang paling ringan dan hampir setiap ibu post partum mengalami baby blues. Pada saat pengkajian klien 1 
merupakan post partum hari ke 7 dan klien 2 merupakan post partum hari ke 5, menurut Asih dan Risneni (2016 ) baby bluesdapat terjadi sejak hari pertama setelah persalinan dan cenderung akan memburuk pada hari ketiga sampai kelima dan berlangsung kurang dari 14 hari pasca melahirkan.

Klien 1 dan 2 merupakan ibu post partum yang baru saja melahirkan anak pertamanya, menurut Asih dan Risneni (2016) Baby blues seringkali dialami oleh ibu postpartum khususnya pada ibu post partum kelahiran anak pertama,yang mana kelahiran seorang bayi menegaskan suatu status baru bagi seorang perempuan yaitu menjadi seorang ibu, adanya status baru ini menuntut ibu untuk melakukan berbagai penyesuaian salah satu bentuk penyesuaian yang harus dilakukan oleh seorang ibu yang baru melahirkan adalah mengikuti ritme kehidupan bayi. Keharusan untuk melakukan penyesuaian ini menyebabkan ibu sangat tertekanyang mengakibatkan stres baik secara fisik maupun psikologis.

Pada klien 1 yang baru saja melahirkan anak pertamanya nya mengatakan sangat kelelahan dalam mengurus bayinya, klien juga mengatakan waktu istirahatnya sangat kurang karena bayinya yang rewel, klien mengeluh sulit untuk mengawali tidur dan mengeluh sering sakit kepala, juga sulit untuk berkonsentrasi. Klien tampak lesu dan juga kurang berkonsentrasi saat diajak berbicara, sesuai dengan pendapat Asih dan Risneni
(2016) gejala yang dialami klien 1 merupakan beberapa tanda dan gejala ibu mengalami baby blues, ibu merasa tertekan sehingga mengalami stress fisik maupun psikologis yang akhirnya menimbulkan gejala tersebut. Saat dilakukan skriningedinburgh postnatal depression scale nilai pada klien 1 yaitu 10, yang mana berarti klien 1 mengalami baby blues.

Pada klien 2 yang juga baru saja melahirkan anak pertamanya, klien mengatakan lelah dalam mengurus bayinya dan mengatakan kurang istirahat klien juga mengatakan sedih dan juga cemas terhadap kemampuan merawat bayinya karena klien belum mempunyai pengalaman menjadi orang tua dan klien mengeluh merasa belum mampu untuk mengurus bayinya. Klien 2 terlihat gelisah dan juga tidak percaya diri, sesuai dengan pendapat Asih dan Risneni (2016) gejala yang dialami klien 2 merupakan beberapa tanda dan gejala ibu mengalami baby blues, ibu merasa tertekan sehingga mengalami stress fisik maupun psikologis yang akhirnya menimbulkan gejala tersebut. Saat dilakukan skrining edinburgh postnatal depression scale nilai pada klien 2 yaitu 12, yang mana berarti klien 2 mengalami baby blues.

Tanda dan gejala yang dirasakan oleh kedua responden merupakan gangguan perasaan setelah melahirkan, klien merasakan stres baik secara fisik maupun psikologis atau yang disebut denganbaby blues. Baby blues 
merupakan depresi postpartum yang paling ringan sehingga harus segera ditangani agar tidak menjadi depresi yang lebih berat yaitu menjadi depresi postpartum dan post partum psikosis.

Hasil penelitian terapi musik klasik Mozart pada ibu post partum yang mengalami baby blues di wilayah kerja puskesmas Gedong Air Bandar Lampung menunjukkan nilai EPDS 10 pada klien 1 dan nilai EPDS 12 pada klien 2 sebelum diberikan terapi musik klasik Mozart. Setelah diberikan terapi musik klasik Mozart selama tiga hari berturut-turut nilai EPDS pada klien 1 menurun menjadi 5 dan pada klien 2 nilai EPDS menurun menjadi 7.

Hal ini sesuai dengan teori yang dikemukakan oleh Permatasari et al (2015), bahwa terapi musik berperan sebagai salah satu teknik relaksasi untuk memperbaiki, memelihara, mengembangkan mental fisik dan kesehatan emosi atau psikologis. Terapi musik sering digunakan karena sangat mudah dilakukan dan efektifitasnya menunjukkan betapa besar musik dalam mempengaruhi ketegangan atau kondisi rileks pada diri seseorang, terapi musik membantu ibu post partum yang mengalami baby bluesmengeluarkan perasaan mereka, membuat perubahan positif dengan suasana hati, membantu memecahkan masalah dan mengurangi stress, serta mengalihkan perhatian klien dari gejala yang tidak menyenangkan.
Menurut Permatasari et al (2015) saat diberikan terapi musik klasik Mozart pada ibu post partum yang mengalami baby blues, musik tersebut akan merangsang pengeluaran gelombang otak yang dikenal sebagai gelombang a yang memiliki frekuensi 8 sampai 12 cps (cycles per second). Pada saat gelombang a dikeluarkan otak memproduksi serotonin yang membantu menjaga perasaan bahagia dan membantu dalam menjaga mood, dengan cara membantu memudahkan klien mengawali tidur, perasaan tenang serta melepaskan depresi dan endorphin yang menyebabkan seseorang merasa nyaman tenang. Saat peneliti memberikan penerapan terapi musik klasik Mozart pada kedua responden selama 3 hari berturut turut dengan durasi 30 menit, setiap harinya nilai EPDS pada kedua responden berkurang, yang mana ibu merasakan lebih tenang dan rileks serta menciptakan pikiran yang positif saat mendengarkan terapi musik klasik Mozart, sehingga tanda dan gejala baby blues pada kedua responden berkurang.

Dengan demikian jelas bahwa terapi musik klasik mozart berpengaruh dalam mengurangi gejala baby blues pada kedua responden.

Hal ini sejalan dengan penelitian Manurung, dkk (2015) yang berjudul "Efektifitas terapi musik terhadap pencegahan Post Partum blues", menunjukkan hasil bahwa ada pengaruh terapi musik pada kelompok intervensi $(\mathrm{p}<0,05)$ dan kelompok kontrol mempunyai resiko mengalami Baby 
bluessebesar 7 kali dibanding kelompok intervensi. Hal ini menunjukkan bahwa terapi musik klasik Mozart berpengaruh sebagai penanganan baby blues. Hal ini juga sejalan dengan Penelitian yang dilakukan oleh (Permatasari, 2015) yang membuktikan bahwa terapi musik klasik Mozart dapat memberikan perasaan rileks dan tenang pada ibu yang mengalami baby blues. Sehingga dapat disimpulkan bahwa terdapat pengaruh terapi musik klasik Mozart dalam meenurunkan gejala baby blues pada ibu post partum di wilayah kerja Puskesmas Gedong Air Bandar Lampung.

\section{KESIMPULAN}

Sebelum dilakukan terapi musik klasik Mozart kedua subjek mengalami baby blues dibuktikan dengan nilai edinburgh postnatal depression scale pada Ny. L yaitu dengan nilai 10 dan pada Ny. E dengan nilai 12 . Setelah dilakukan terapi musik klasik Mozart kedua subjek mengalami penurunan gejala baby blues dibuktikan dengan edinburgh postnatal depression scale pada $\mathrm{Ny}$. L dengan nilai 5 dan pada Ny. E dengan nilai 7.

Pemberian intervensi Terapi musik klasik Mozart berpengaruh dalam menurunkan gejala baby blues pada ibu postpartum di wilayah kerja puskesmas Gedong Air Bandar Lampung.

\section{KEPUSTAKAAN}

Asih,Y dan risneni. 2016. Asuhan Kebidanan Nifas dan Menyusui. Cetakan 1, Trans Info media. Jakarta.

Dewi,F. dan Sunarsih, T. 2012. Asuhan Kebidanan Pada Ibu Nifas. Salemba Medika. Jakarta Selatan.

Dwi permatasari, I. Misrowati dan hasanah, O. 2015. Efektifitas Terapi Musik Klasik Mozart. Program Studi Ilmu Keperawatan Universitas Riau.

Manurung,S. Lestari, T . Suryati, dan Miradwiyana,B. 2016. Efektifitas Terapi Musik Terhadap Pencegahan Postpartum Blues pada ibu Primipara di Ruang Kebidanan RSUP Cipto mangunkusumo. Jakarta .

Marmi, S. 2012. Asuhan Kebidanan Pada Ibu Nifas "Peurperium Care". Pustaka Belajar. Yogyakarta

Susanti, L dan Sulistiyani, A. 2017.Analisis Faktor faktor Penyebab terjadinya Baby blues pada ibu nifas. Infokes, Vol 7, No 2.Surakarta 